\title{
Development of Small Molecules Activating TRAIL Apoptosis Pathway for Cancer Therapies
}

\author{
Anita C. Bellail, Chunhai Hao \\ Emory University School of Medicine, Atlanta, USA \\ Email: chao@emory.edu
}

Received August 15, 2013; revised September 20, 2013; accepted September 30, 2013

Copyright (C) 2013 Anita C. Bellail, Chunhai Hao. This is an open access article distributed under the Creative Commons Attribution License, which permits unrestricted use, distribution, and reproduction in any medium, provided the original work is properly cited.

\section{Dear Readers}

It has been thirty-eight years since tumor necrosis factor- $\alpha(\mathrm{TNF} \alpha)$ was isolated and found with cancer therapeutic potential in 1975 [1]; however, all the efforts have failed in the development of TNF $\alpha$ and its family ligands as cancer drugs [2] first due to the lethal toxicity of TNF $\alpha$ and Fas ligand (FasL) [3,4]. In the middle 1990s, tumor necrosis factor-related apoptosis-inducing ligand (TRAIL; Apo2 ligand, Apo2L) was identified as a member of the TNF ligand family [5,6] that can induce apoptosis in cancer cells without the toxicity as caused by TNF $\alpha$ and FasL $[7,8]$, leading to renewed efforts in development of this TNF family ligand as a cancer therapeutic. TRAIL is a type II membrane protein that is normally expressed on the surface of immune cells in execution of innate and adaptive immunity against cancers in immunosurveillance [9]. TRAIL has a short intracellular $\mathrm{N}$-terminal tail and a long extracellular C-terminal with the receptor-binding domain [10]; thus, recombinant human TRAIL (rhTRAIL) of the C-terminal has been generated as a cancer drug (rhApoL/TRAIL; dulanermin). Phase I trials approved the safety of rhTRAIL in patients $[11,12]$; however, phase II trial revealed the drug resistance of human solid cancers [13].

TRAIL-induced apoptosis occurs through the binding of its cognate receptors, TRAIL receptor 1 (TRAIL-R1; death receptor 4, DR4) and TRAIL-R2 (DR5) on the surface of cancer cells; DR4 and DR5 become trimerized and recruit intracellular Fas-associate death domain (FADD) and apoptosis-initiating caspase-8 in assembly of a death-inducing signaling complex (DISC), where caspase-8 is dimerized, cleaved and activated in the initiation of the extrinsic apoptotic pathway [2]. In addition, caspase-8 enzymes cleave the Bid and activate the intrinsic mitochondrial pathway with the release of the apoptotic proteins including the second mitochondrial-derived activator of caspases (Smac). To target DR5, a mouse monoclonal antibody against human DR5 (TRA-8) was generated for antitumor activity but no hepatotoxicity
[14]. This DR5 agonistic mouse monoclonal antibody was humanized as a therapeutic (CS-1008; tigatuzumab) [15] and passed the safety evaluation in a phase I trial [16]. Advances in antibody technology led to the generation of fully human monoclonal antibodies against DR4 and DR5 for activation of TRAIL apoptotic pathway in cancer cells [17]. Phase I trials evaluated the safety of the DR4 agonistic antibody HGS-ETR1 (mapatumumab), the DR5 agonistic antibodies HGS-ERT2 (lexatumumab) and PRO95780 (drozitumab) [18-20]. Once again, however, phase II trials failed to show clinical anticancer activity of HGS-ETR1 [21,22] and PRO95780, as reported at the 2010 Annual Meeting of the American Society of Clinical Oncology. Cleary, the drug resistance now is the roadblock in development of TRAIL agonists as cancer drugs.

TRAIL is a natural cancer killer in immunosurveillance [9]; however, this notion also predicts that cancer occurs in patients by evasion of TRAIL-mediated immunity; thus, the drug resistance is the inherent nature of cancer. Cancer is a genetic disease and genetic alterations lead to its relentless growth through activation of growth pathways such as phosphatidylinositide-3-kinase (PI3K), AKT and extracellular signal-regulated kinase (ERK) on the one hand and inhibition of cell death pathways on the other hand; thus, current efforts are focused on the development of combination therapies that can block cell growth and activate cell death pathways in cancer cells [2]. From the pharmacokinetic point of view, however, rhTRAIL protein and DR4/DR5 agonistic antibodies as drugs suffer from short half-life and poor tissues distribution. To overcome these limits of protein-drugs, researchers have turned their attention to high-throughput drug screening for small molecules that can activate TRAIL apoptotic pathway in cancer cells.

Biochemical and cell-based assays are the two mainstays in high-through drug screening; yet, cell-based assays are used more now because they represent specific responses of targeted cells. Published in the February 
2013 issue of Science Translational Medicine, the cancer HCT 116 cell-based bioluminescence reporter screening of the National Cancer Institute Diversity Set II led to the discovery of TRAIL-inducing compound 10 (TIC10) [23]. In this study, El-Deiry's lab reported that TIC10 can inactivate AKT and ERK, which leads to the translocation of Foxo3a to the nucleus where this transcriptional factor binds TRAIL promoter and up-regulates TRAIL gene transcription. With the dual activities, TIC10 eliminates the inherent TRAIL resistance in cancers through inhibition of the cell growth pathways and activates TRAIL apoptotic pathway through up-regulation of endogenous TRAIL protein in cancers. The study has provided new direction in development of cancer drugs with the dual activities. The questions now are who the binding partner of TIC10 is and, more importantly, if TIC10 is a drug-like compound. The optimization of this lead compound through structure-activity relationship studies is needed for development of drug-like derivatives for clinical cancer therapies.

Published in the February 2013 issue of Nature Chemical Biology, the report from Wang's lab described the discovery of the small molecule TRAIL mimic bioymifi targeting DR5 for cancer therapy [24]. Bioymifi was identified through structure-activity relationship studies of the small molecule Smac mimetic A2C2, which was identified through a cell based screening of $\sim 200,000$ compounds using the TRAIL-sensitive glioma cell line T98G. Bioymifi binds the extracellular domain of DR5 and causes the aggregation and activation of the receptor for the recruitment of intracellular FADD and caspase-8 and assembly of the DISC in the initiation of TRAILinduced apoptosis. While it is interesting to know how a small molecule can cause the aggregation of this 47,878 Da protein, the study has opened new revenue in development of small molecule DR5 mimics for cancer therapy. Since bioymifi shares the same DR-dependent extrinsic apoptosis pathway, unfortunately, the inherent TRAIL resistance will be the roadblock in development of this molecule as cancer drug as observed with rhTRAIL and DR5 agonistic antibodies.

Small molecule drugs are relatively stable and rapidly diffuse across cell membrane. With these pharmacodynamic advantages, small molecules become attractive as cancer drugs for activating TRAIL/DR5-mediated extrinsic apoptotic pathway. The success in clinical cancer therapy with the TRAIL/DR5 mimics, however, will require better understanding of the mechanism in TRAIL resistance inherent in human cancers.

With warm regards,

Anita C. Bellail, Ph.D.

Chunhai Hao, MD, Ph.D.

Department of Pathology \& Laboratory Medicine

Emory University School of Medicine
Atlanta GA 30322

\section{REFERENCES}

[1] E. A. Carswell, L. J. Old, R. L. Kassel, S. Green, N., Fiore and B. Williamson, "An Endotoxin-Induced Serum Factor that Causes Necrosis of Tumors," Proceedings of the National Academy of Sciences of the United States of America, Vol. 72, No. 9, 1975, pp. 3666-3670. http://dx.doi.org/10.1073/pnas.72.9.3666

[2] A. C Bellail, L. Qi, P. Mulligan, V. Chhabra and C. Hao, "TRAIL Agonists on Clinical Trials for Cancer Therapy: The Promises and the Challenges," Reviews on Recent Clinical Trials, Vol. 4, No. 1, 2009, pp. 34-41. http://dx.doi.org/10.2174/157488709787047530

[3] K. J. Tracey, B. Beutler, S. F. Lowry, J. Merryweather, S Wolpe, I. W. Milsark, R. J. Hariri, T. J. Fahey 3rd, A. Zentella, J. D. Albert, et al., "Shock and Tissue Injury Induced by Recombinant Human Cachectin,” Science, Vol. 234, No. 4775, 1986, pp. 470-474. http://dx.doi.org/10.1126/science.3764421

[4] J. Ogasawara, R. Watanabe-Fukunaga, M. Adachi, A. Matsuzawa, T. Kasugai, Y. Kitamura, N. Itoh, T. Suda, and S. Nagata, "Lethal Effect of the Anti-Fas Antibody in Mice,” Nature, Vol. 364, No. 6440, 1993, pp. 806-809. http://dx.doi.org/10.1038/364806a0

[5] S. R. Wiley, K. Schooley, P. J. Smolak, W. S. Din, C. P. Huang, J. K. Nicholl, G. R. Sutherland, T. D. Smith, C. Rauch, C. A. Smith, et al., "Identification and Characterization of a New Member of the TNF Family That Induces Apoptosis,” Immunity, Vol. 3, No. 6, 1995, pp. 673-682. http://dx.doi.org/10.1016/1074-7613(95)90057-8

[6] R. M. Pitti, S. A. Marsters, S. Ruppert, C. J. Donahue, A. Moore and A. Ashkenazi, "Induction of Apoptosis by Apo-2 Ligand, a New Member of the Tumor Necrosis Factor Cytokine Family,” The Journal of Biological Chemistry, Vol. 271, No. 22, 1996, pp. 12687-12690. http://dx.doi.org/10.1074/jbc.271.22.12687

[7] D. Lawrence, Z. Shahrokh, S. Marsters, K. Achilles, D. Shih, B. Mounho, K. Hillan, K. Totpal, L. DeForge, P. Schow, et al., "Differential Hepatocyte Toxicity of Recombinant Apo2L/TRAIL Versions,” Nature Medicine, Vol. 7, No. 4, 2001, pp. 383-385. http://dx.doi.org/10.1038/86397

[8] C. Hao, J. H. Song, B. Hsi, J. Lewis, D. K. Song, K. C. Petruk, D. L. Tyrrell and N. M. Kneteman, "TRAIL Inhibits Tumor Growth But Is Nontoxic to Human Hepatocytes in Chimeric Mice,” Cancer Research, Vol. 64, No. 23, 2004, pp. 8502-8506. http://dx.doi.org/10.1158/0008-5472.CAN-04-2599

[9] M. J. Smyth, K. Takeda, Y. Hayakawa, J. J. Peschon, M. R. van den Brink and H. Yagita, "Nature's TRAIL-On a Path to Cancer Immunotherapy,” Immunity, Vol. 18, No. 1, 2003, pp. 1-6. http://dx.doi.org/10.1016/S1074-7613(02)00502-2

[10] S. S. Cha, M. S. Kim, Y. H. Choi, B. J. Sung, N. K. Shin, H. C. Shin, Y. C. Sung and B. H. Oh, "2.8 Å Resolution Crystal Structure of Human TRAIL, a Cytokine with Se- 
lective Antitumor Activity,” Immunity, Vol. 11, No. 2, 1999, pp. 253-261. http://dx.doi.org/10.1016/S1074-7613(00)80100-4

[11] R. S. Herbst, S. G. Eckhardt, R. Kurzrock, S. Ebbinghaus, P. J. O’Dwyer, M. S. Gordon, W. Novotny, M. A. Goldwasser, T. M. Tohnya, B. L. Lum, et al., "Phase I Dose-Escalation Study of Recombinant Human Apo2L/ TRAIL, a Dual Proapoptotic Receptor Agonist, in Patients with Advanced Cancer," Journal of Clinical Oncology, Vol. 28, No. 17, 2010, pp. 2839-2846. http://dx.doi.org/10.1200/JCO.2009.25.1991

[12] J. C. Soria, E. Smit, D. Khayat, B. Besse, X. Yang, C. P. Hsu, D. Reese, J. Wiezorek and F. Blackhall, "Phase 1b Study of Dulanermin (Recombinant Human Apo2L/ TRAIL) in Combination with Paclitaxel, Carboplatin, and Bevacizumab in Patients with Advanced Non-Squamous Non-Small-Cell Lung Cancer,” Journal of Clinical Oncology, Vol. 28, No. 9, 2010, pp. 1527-1533. http://dx.doi.org/10.1200/JCO.2009.25.4847

[13] J. C. Soria, Z. Mark, P. Zatloukal, B. Szima, I. Albert, E. Juhasz, J. L. Pujol, J. Kozielski, N. Baker, D. Smethurst, et al., "Randomized Phase II Study of Dulanermin in Combination with Paclitaxel, Carboplatin, and Bevacizumab in Advanced Non-Small-Cell Lung Cancer,” Journal of Clinical Oncology, Vol. 29, No. 33, 2011, pp. 4442-4451. http://dx.doi.org/10.1200/JCO.2011.37.2623

[14] K. Ichikawa, W. Liu, L. Zhao, Z. Wang, D. Liu, T. Ohtsuka, H. Zhang, J. D. Mountz, W. J. Koopman, R. P. Kimberly, et al., "Tumoricidal Activity of a Novel AntiHuman DR5 Monoclonal Antibody without Hepatocyte Cytotoxicity,” Nature Medicine, Vol. 7, No. 8, 2001, pp. 954-960. http://dx.doi.org/10.1038/91000

[15] A. Yada, M. Yazawa, S. Ishida, H. Yoshida, K. Ichikawa, S. Kurakata and K. Fujiwara, "A Novel Humanized AntiHuman Death Receptor 5 Antibody CS-1008 Induces Apoptosis in Tumor Cells without Toxicity in Hepatocytes,” Annals of Oncology, Vol. 19, No. 6, 2008, pp. 1060-1067. http://dx.doi.org/10.1093/annonc/mdn015

[16] A. Forero-Torres, J. Shah, T. Wood, J. Posey, R. Carlisle, C. Copigneaux, F. R. Luo, S. Wojtowicz-Praga, I. Percent, and M. Saleh, "Phase I Trial of Weekly Tigatuzumab, an Agonistic Humanized Monoclonal Antibody Targeting Death Receptor 5 (DR5)," Cancer Biotherapy \& Radiopharmaceuticals, Vol. 25, No. 1, 2010, pp. 13-19. http://dx.doi.org/10.1089/cbr.2009.0673

[17] R. C. Humphreys and W. Halpern, "Trail Receptors: Targets for Cancer Therapy,” Advances in Experimental Medicine and Biology, Vol. 615, 2008, pp. 127-158. http://dx.doi.org/10.1007/978-1-4020-6554-5_7

[18] A. W. Tolcher, M. Mita, N. J. Meropol, M. von Mehren, A. Patnaik, K. Padavic, M. Hill, T. Mays, T. McCoy, N.
L. Fox, et al., "Phase I Pharmacokinetic and Biologic Correlative Study of Mapatumumab, a Fully Human Monoclonal Antibody with Agonist Activity to Tumor Necrosis Factor-Related Apoptosis-Inducing Ligand Receptor-1,” Journal of Clinical Oncology, Vol. 25, No. 28, 2007, pp. 1390-1395. http://dx.doi.org/10.1200/JCO.2006.08.8898

[19] R. Plummer, G. Attard, S. Pacey, L. Li, A. Razak, R. Perrett, M. Barrett, I. Judson, S. Kaye, N. L. Fox, et al., "Phase 1 and Pharmacokinetic Study of Lexatumumab in Patients with Advanced Cancers," Clinical Cancer Research, Vol. 13, No. 20, 2007, pp. 6187-6194. http://dx.doi.org/10.1158/1078-0432.CCR-07-0950

[20] D. R. Camidge, R. S. Herbst, M. S. Gordon, S. G. Eckhardt, R. Kurzrock, B. Durbin, J. Ing, T. M. Tohnya, J. Sager, A. Ashkenazi, et al., "A Phase I Safety and Pharmacokinetic Study of the Death Receptor 5 Agonistic Antibody PRO95780 in Patients with Advanced Malignancies,” Clinical Cancer Research, Vol. 16, No. 4, 2010, pp. 1256-1263. http://dx.doi.org/10.1158/1078-0432.CCR-09-1267

[21] F. A Greco, P. Bonomi, J. Crawford, K. Kelly, Y. Oh, W. Halpern, L. Lo, G. Gallant and J. Klein, "Phase 2 Study of Mapatumumab, a Fully Human Agonistic Monoclonal Antibody Which Targets and Activates the TRAIL Receptor-1, in Patients with Advanced Non-Small Cell Lung Cancer,” Lung Cancer, Vol. 61, No. 1, 2008, pp. 82-90. http://dx.doi.org/10.1016/j.lungcan.2007.12.011

[22] T. Trarbach, M. Moehler, V. Heinemann, C. H. Kohne, M. Przyborek, C. Schulz, V. Sneller, G. Gallant and S. Kanzler, "Phase II Trial of Mapatumumab, a Fully Human Agonistic Monoclonal Antibody That Targets and Activates the Tumour Necrosis Factor Apoptosis-Inducing Ligand Receptor-1 (TRAIL-R1), in Patients with Refractory Colorectal Cancer," British Journal of Cancer, Vol. 102, No. 3, 2010, pp. 506-512. http://dx.doi.org/10.1038/sj.bjc.6605507

[23] J. E. Allen, G. Krigsfeld, P. A. Mayes, L. Patel, D. T. Dicker, A. S. Patel, N. G. Dolloff, E. Messaris, K. A. Scata, W. Wang, et al., "Dual Inactivation of Akt and ERK by TIC10 Signals Foxo3a Nuclear Translocation, TRAIL Gene Induction, and Potent Antitumor Effects," Science Translational Medicine, Vol. 5, No. 171, 2013, p.171ra17. http://dx.doi.org/10.1126/scitranslmed.3004828

[24] G. Wang, X. Wang, H. Yu, S. Wei, N. Williams, D. L. Holmes, R. Halfmann, J. Naidoo, L. Wang, L. Li, et al., "Small-Molecule Activation of the TRAIL Receptor DR5 in Human Cancer Cells,” Nature Chemical Biology, Vol. 9, 2013, pp. 84-89.

http://dx.doi.org/10.1038/nchembio.1153 